\title{
Tetrahedron Probes for Ultrasensitive in Situ Detection of Telomerase and Surface Glycoprotein Activity in Living Cells
}

\author{
Xiao Guo, Xiaoling Wu, Maozhong Sun ${ }^{*}$, Liguang Xu, Hua Kuang ${ }^{*}$, Chuanlai Xu* \\ International Joint Research Laboratory for Biointerface and Biodetection, State Key Lab of Food Science and \\ Technology, School of Food Science and Technology, Jiangnan University, Wuxi, Jiangsu, 214122, PRC. \\ *Corresponding Authors: smzjscz@163.com; kuangh@jiangnan.edu.cn; xcl@jiangnan.edu.cn;
}

\section{Table of Contents}

Chemical reagents and instrumentation......................................

Synthesis of Au NPs....................................................s

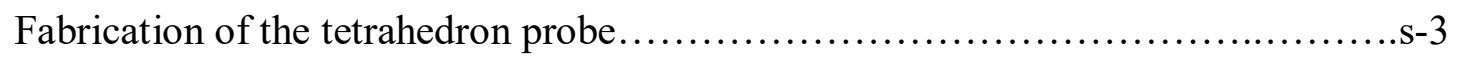

Feasibility of the tetrahedron probe........................................ 4

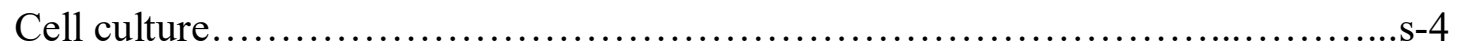

Cellular toxicity and viability of the tetrahedron probe..........................s 4

Confocal fluorescence microscopy imaging ...............................s 5

Raman microscopy imaging ............................................. 5

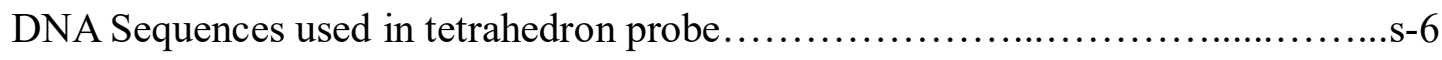




\section{Chemical reagents and instrumentation}

All chemical reagents used in the study were obtained from Sigma-Aldrich (Shanghai,

P.R. China). The thiolated DNA oligonucleotides (purified by high-performance liquid chromatography) and the cell-penetrating peptide (TAT) were manufactured by Sangon Biological Engineering Technology Co., Ltd (Shanghai, P.R. China). The EpCAM and telomerase ELISA Kits were obtained from MultiSciences Tech Co., Ltd (Hangzhou, P.R. China). The HeLa (human epithelial carcinoma) and MCF-7 (human breast cancer) cell lines were obtained from the China Center for Type Culture Collection (Wuhan, P.R. China). PCS-460-010 (normal human epithelial) cells were purchased from the American Type Culture Collection (Manassas, VA, USA). All aqueous solutions were prepared with ultrapure water obtained using a Milli-Q device (18.2 MS; Milli-Q, Molsheim, France).

TEM images were acquired with a JEOL JEM-2100 transmission electron microscope (operated at an acceleration voltage of $200 \mathrm{kV}$ ). The UV-Vis results were acquired with a UNICO 2100 PC UV-Vis spectrophotometer. Hydrodynamic sizes of NPs and assemblies were monitored with a Zetasizer Nano ZS system (Malvern Instruments Ltd., Malvern, UK) with a $532 \mathrm{~nm}$ laser. Raman scattering spectra were measured in a liquid cell using a LabRam-HR800 Micro-Raman spectrometer with Labspec 5.0 software. The slit and pinhole were set at 100 and $400 \mathrm{~mm}$, respectively, with an air-cooled $\mathrm{He}-\mathrm{Ne}$ laser for $532 \mathrm{~nm}$ excitation and power of approximately $8 \mathrm{~mW}$. Confocal imaging was performed with a Leica TCS SP8 confocal3 fluorescence microscope. Raman images were observed on a Renishaw inVia confocal Raman 
microscope (Renishaw, UK) at $785 \mathrm{~nm}$ excitation.

\section{Synthesis of Au NPs}

The glassware used in this study was cleaned by soaking in aqua regia. $15 \mathrm{~nm}$ and 30 $\mathrm{nm} \mathrm{Au}$ NPs were synthesized by a classical method in which trisodium citrate reduced $\mathrm{HAuCl}_{4} .5 \mathrm{~mL} 4 \mathrm{~g} / \mathrm{L} \mathrm{HAuCl}_{4}$ were added to $195 \mathrm{~mL}$ ultra-pure water and then boiled at $300^{\circ} \mathrm{C}$. $5 \mathrm{~mL}$ or $2.8 \mathrm{~mL} 1 \%$ trisodium citrate was then added and quickly mixed to obtain $15 \mathrm{~nm}$ or $30 \mathrm{~nm}$ Au NPs. The solution was heated and stirred until it turned brilliant red and was then cooled to room temperature. In order to improve the stability of NPs in solution, $2.5 \mathrm{mg} / \mathrm{mL}$ Bis (p-sulfonatophenyl) phenylphosphine dihydrate dipotassium salt was added and stirred overnight. The solution was then stored at $4^{\circ} \mathrm{C}$.

\section{Fabrication of the tetrahedron probe}

The tag-modified $30 \mathrm{~nm}$ Au NPs were mixed with ssDNA1 and DNA3 respectively in a ratio of $1: 25$ for 4 h. $2 \mu \mathrm{L} \mathrm{NaCl}(5 \mathrm{M})$ was then added and centrifuged after $12 \mathrm{~h}$ to remove any uncoupled oligonucleotide. Here, two different types of Au NPs-DNA conjugates were prepared, they were $\mathrm{Au}_{30}-\mathrm{DNA} 1$ and $\mathrm{Au}_{30}-\mathrm{DNA3}$. The same procedure was used for the preparation of conjugates $\mathrm{Au}_{15}$-DNA5, $\mathrm{Au}_{15}$-DNA6 and Au15-DNA7. In the first stage, dimer and trimer were prepared. $\mathrm{Au}_{30}$-DNA1 and $\mathrm{Au}_{30}$-DNA3 were mixed with equal volume, then DNA2 and DNA4 were added and incubated for $12 \mathrm{~h}$ to obtain dimer. $\mathrm{Au}_{15}$-DNA5, $\mathrm{Au}_{15}$-DNA6 and $\mathrm{Au}_{15}$-DNA7 were mixed for $12 \mathrm{~h}$ to obtain trimer. In the second staged, tetrahedron was assembled by hybridizing the dimer and trimer for $12 \mathrm{~h}$ at room temperature. The tetrahedron was then centrifuged (4000 $\mathrm{rpm}, 10 \mathrm{~min}$ ) and dispersed in water for further experimentation. 


\section{Feasibility of the tetrahedron probe}

After the probe mixing with TE $\left(10 \times 10^{-12} \mathrm{IU}\right)$ and EpCAM $(3.33 \mathrm{pg} / \mathrm{mL})$ in PBS for different time periods, the Raman scattering was recorded from $200 \mathrm{~cm}^{-1}$ to $2000 \mathrm{~cm}^{-1}$ under excitation at $532 \mathrm{~nm}$ with a $10 \mathrm{~mm}$ cuvette to determine the efficiency in vitro. The probe $(20 \mathrm{nM})$ was dispersed in PBS containing different levels of TE $(0,0.1,0.5$, 1, 5, and $\left.10 \times 10^{-12} \mathrm{IU}\right)$ and $\operatorname{EpCAM}(0,0.03,0.17,0.33,1.67$, and $3.33 \mathrm{pg} / \mathrm{mL})$ for simultaneous detection in vitro. The Raman intensities were detected after $1 \mathrm{~h}$, and the intensity ratios were calculated. Standard curves were prepared with the Raman intensity ratio ( $\mathrm{I}_{1346} / \mathrm{I}_{1096}$ and $\left.\mathrm{I}_{1614} / \mathrm{I}_{1096}\right)$ and level of TE and EpCAM, respectively.

\section{Cell culture}

HeLa, MCF-7 and PCS cells were cultured in RPMI-1640 (Gibco, Gaithersburg, MD, USA) supplemented with 10\% fetal bovine serum (FBS; Sigma-Aldrich, St. Louis, MO, USA), penicillin and streptomycin $(100 \mu \mathrm{g} / \mathrm{mL})$ at $37^{\circ} \mathrm{C}$ in a humidified atmosphere containing 5\% $\mathrm{CO}_{2}$. Cell numbers were determined with a Petroff Hausser cell counter (Horsham, PA, USA).

\section{Cellular toxicity and viability of the tetrahedron probe}

TAT was incubated with tetrahedron probe in a ratio of $20: 1$ for $12 \mathrm{~h}$ at room temperature to ensure probe could enter the cells. The cytotoxicity of the probe in HeLa cells was determined using the CCK-8 kit, and the optimal concentration of the probe was determined.

For detection, the probe $(5 \mathrm{nM})$ was incubated with $\mathrm{HeLa}$ cells at $37^{\circ} \mathrm{C}$ with $5 \% \mathrm{CO}_{2}$ for different time periods and the Raman intensity of the cell suspension was then 
determined. The time-dependent $(0-4 \mathrm{~h})$ dynamic SERS spectrum was obtained to verify the optimal detection time in cells.

\section{Confocal fluorescence microscopy imaging}

HeLa cells treated or untreated were cultured in Petri dishes $\left(1 \mathrm{~mL} / \mathrm{dish}, 10^{5}\right.$ cells $\left./ \mathrm{mL}\right)$ for $12 \mathrm{~h}$, and then the $5 \mathrm{nM}$ probe was added and incubated for $4 \mathrm{~h}$. Cold PBS was used to remove unattached cells. The cells were fixed with $4 \%$ paraformaldehyde solution for 20 min before obtaining images by confocal fluorescence microscopy.

\section{Raman microscopy imaging}

Pretreatment of cells was the same as for confocal imaging. Based on the map image acquisition mode, the following conditions were set: static scan type with an exposure time of $1 \mathrm{~s}$ under excitation at $785 \mathrm{~nm}, 100 \%$ laser power, with imaging steps at $2 \mu \mathrm{m} \times 3$ $\mu \mathrm{m}$. The characteristic peaks for tags were $1096 \mathrm{~cm}^{-1}, 1346 \mathrm{~cm}^{-1}$ and $1614 \mathrm{~cm}^{-1}$; therefore, the Raman images were acquired from $1050 \mathrm{~cm}^{-1}$ to $1150 \mathrm{~cm}^{-1}, 1300 \mathrm{~cm}^{-1}$ to $1400 \mathrm{~cm}^{-1}$, and $1560 \mathrm{~cm}^{-1}$ to $1660 \mathrm{~cm}^{-1}$, with WIRE 3.4 software. 
Table S1. DNA Sequences used in tetrahedron probe.

\begin{tabular}{|c|c|c|}
\hline $\begin{array}{l}\text { Sequence } \\
\text { Name }\end{array}$ & $\begin{array}{c}\text { 5'-3' DNA sequences, the underlined nucleotides are } \\
\text { phosphorothioate-modified }\end{array}$ & Modification \\
\hline DNA1 & $\begin{array}{l}\text { TTTTGTCCGGTTGGGGGGTACTGTTGCACCCTG } \\
\text { TCTGCGTTGGAGACATCAC }\end{array}$ & $\begin{array}{c}\text { 5' } \mathrm{SH} \\
\text { 3'-TAMRA }\end{array}$ \\
\hline DNA2 & $\begin{array}{l}\text { AGGCAGCTCGTCTCAAAATCCCAATCCCAATT } \\
\text { TTTAATCGGTTCCACGGGTAACACCGGATATC } \\
\text { AATCCGTTTTTCCGATGGCAATCCGGGATCAG } \\
\text { TTAGCTTATCAG }\end{array}$ & \\
\hline DNA3 & TTTGGGATATGGATA & $\begin{array}{l}\text { 5’ } \mathrm{SH} \\
\text { 3'-CY5.5 }\end{array}$ \\
\hline DNA4 & $\begin{array}{l}\text { TGAGACGAGCTGCCTAAGTGATGTCTCCAACC } \\
\text { CCCAACCGGACTTTTAAGTTGTAGCTTATCAG } \\
\text { CTGACTACATTGTCAAGTAGCTTTTAAGTTGTA } \\
\text { GCTTATCAGCTGACTACATTGTCAAGT }\end{array}$ & \\
\hline DNA5 & $\begin{array}{l}\text { TTTTTATCAGTTACAGCTCGCAGGATACGATC } \\
\text { CATGAAGCTTATGAGTTACAGCTCGCTTTTGG } \\
\text { CTACCGTTAGGCCCTAGTCAATCGAATAGTCT } \\
\text { TTTTTCAACATCGAATAGTCGACTGATGTAAC } \\
\text { AGTTCATCG }\end{array}$ & 5' $\mathrm{SH}$ \\
\hline DNA6 & $\begin{array}{l}\text { TTTTACGGATTGATATCCGGTGTTACCCGTGG } \\
\text { AACCGATTTTTTACTTGACAATGTAGTCAGCT } \\
\text { GATAAGCTACAACTTTTTTATAGTCAATGTCG } \\
\text { AGCGTCCTATGCTA }\end{array}$ & 5' $\mathrm{SH}$ \\
\hline DNA7 & TTTTCGAATAGTCAATGTCGAGCG & $5^{\prime} \mathrm{SH}$ \\
\hline TE Primer & TTTTTTAATCCGTCGAGCAGAGTT & \\
\hline $\begin{array}{l}\text { EpCAM } \\
\text { Aptamer }\end{array}$ & $\begin{array}{l}\text { GTCCGGTTGGGGGGTACTGTTGCACCCTGTCT } \\
\text { GCGTTGGAGACATCAC }\end{array}$ & \\
\hline
\end{tabular}



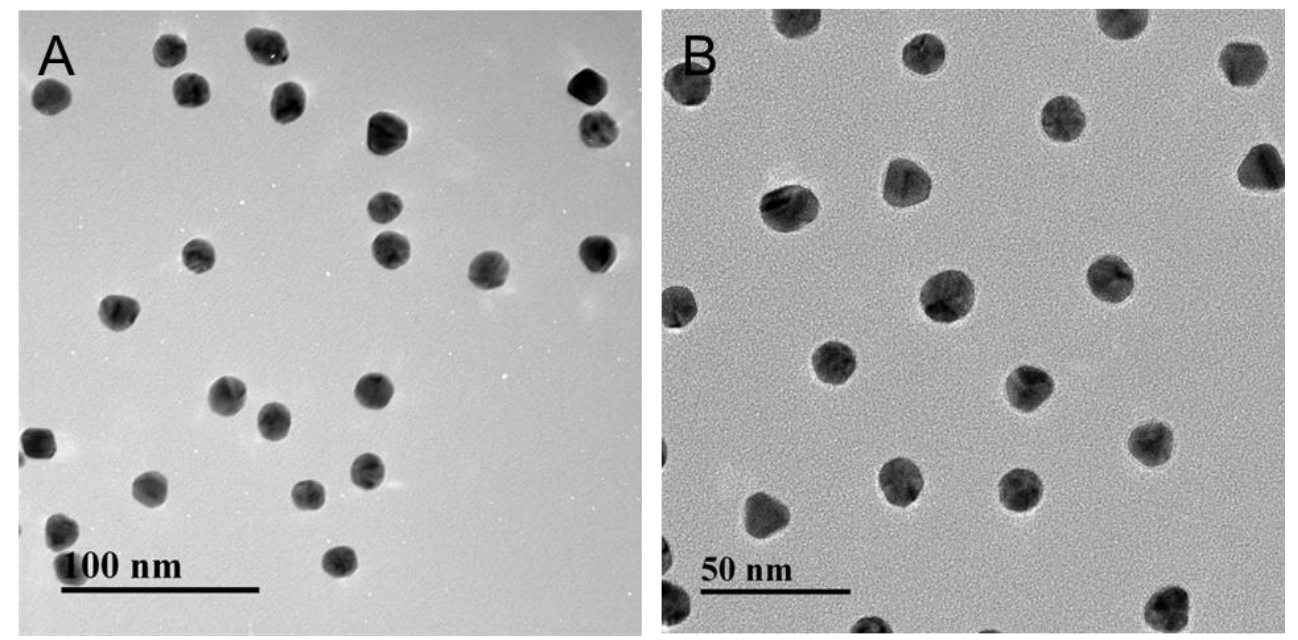

Figure S1. TEM of A) $30 \mathrm{~nm} \mathrm{Au} \mathrm{NPs,} \mathrm{B)} \mathrm{15nm} \mathrm{Au} \mathrm{NPs.}$

3 

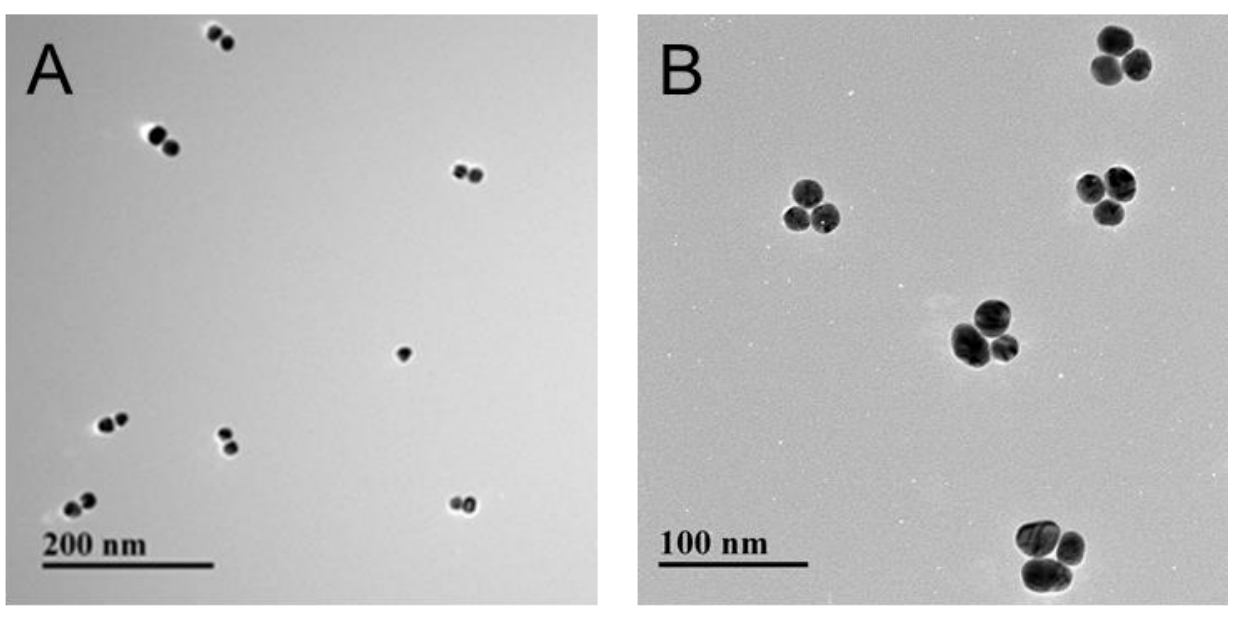

5
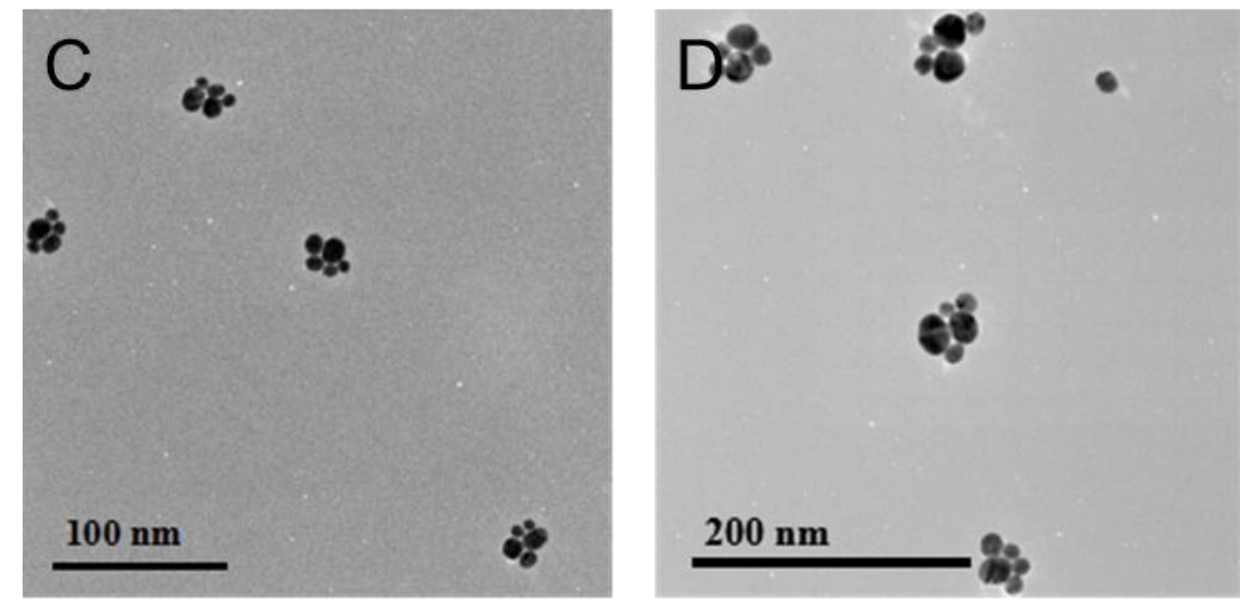

Figure S2. TEM of A) $30 \mathrm{~nm}$ Au NPs dimer, B) $15 \mathrm{~nm} \mathrm{Au} \mathrm{NPs} \mathrm{trimer,} \mathrm{C-D)}$ 7 tetrahedron probes.

8 


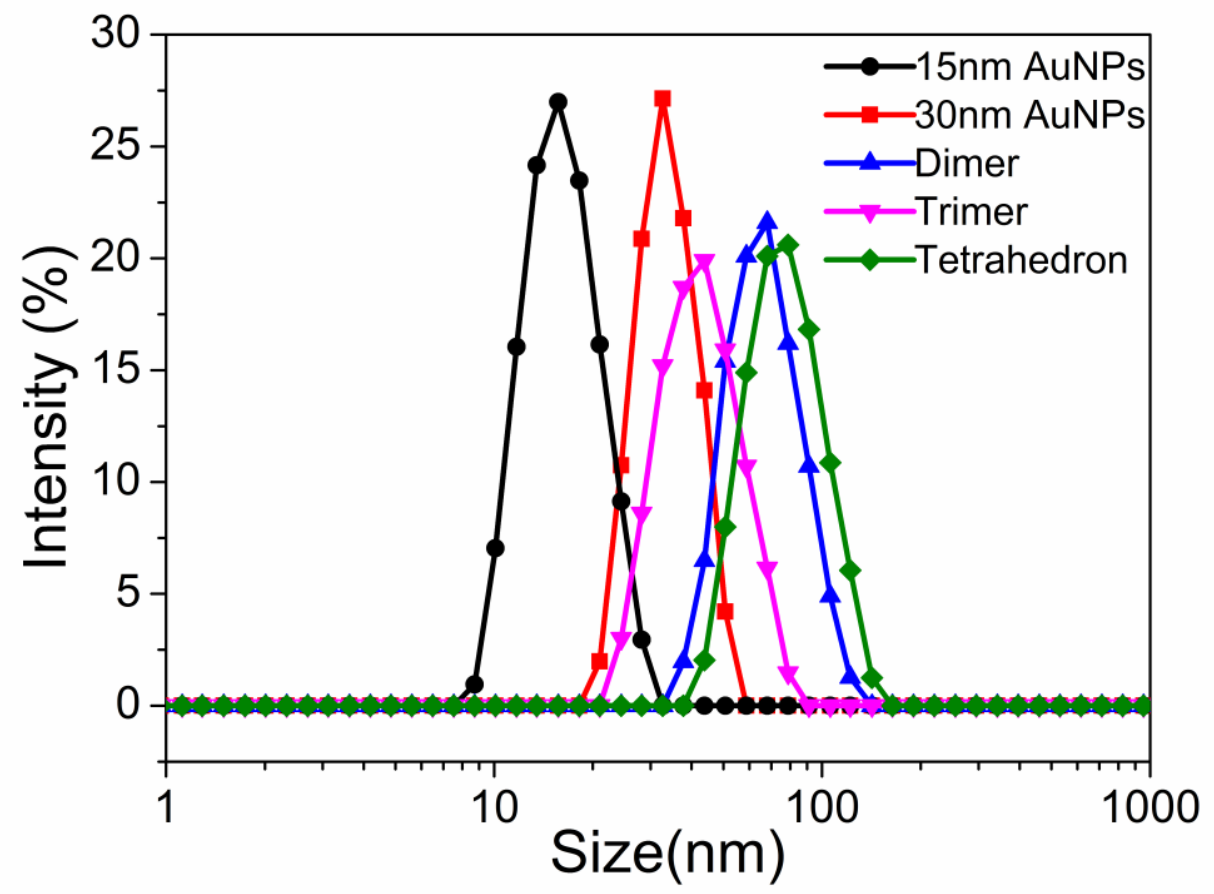

Figure S3. DLS of $15 \mathrm{~nm}$ Au NPs, $30 \mathrm{~nm} \mathrm{Au} \mathrm{NPs,} 15 \mathrm{~nm}$ Au NPs trimer, $30 \mathrm{~nm} \mathrm{Au}$ NPs dimer and tetrahedron. 

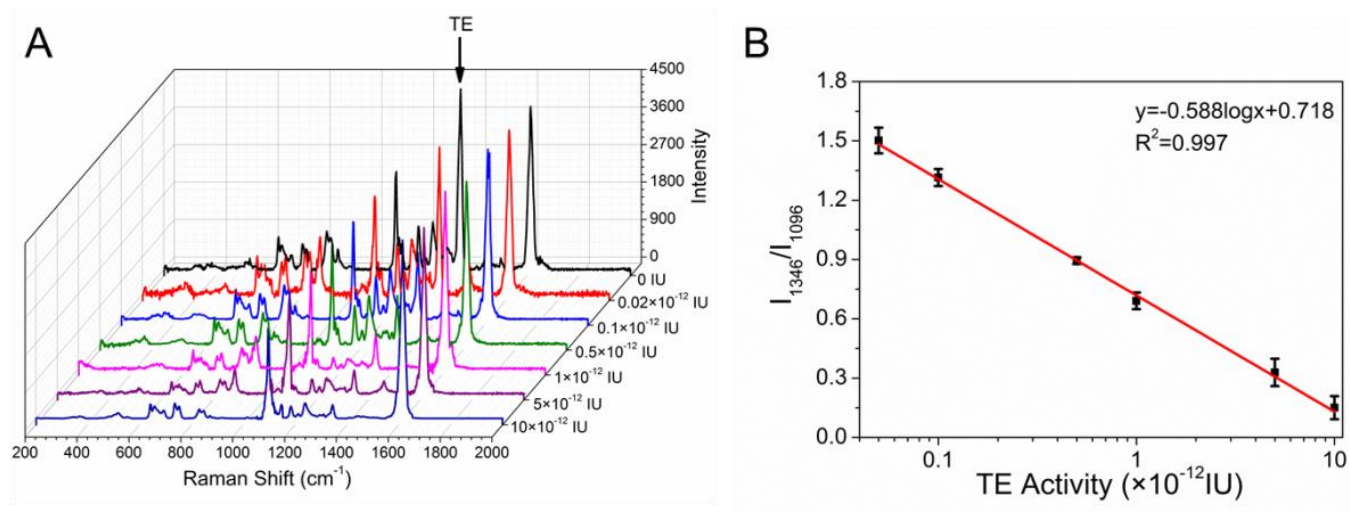

13

14

15

16

17

Figure S4. Probes for TE in vitro detection. A) SERS spectra of probes responded to different activities of TE $\left(0,0.02,0.1,0.5,1,5\right.$ and $\left.10 \times 10^{-12} \mathrm{IU}\right)$ in PBS. B) A plot of Raman intensity ratio $\left(\mathrm{I}_{1346} / \mathrm{I}_{1096}\right)$ as a function with different activities TE in PBS. 

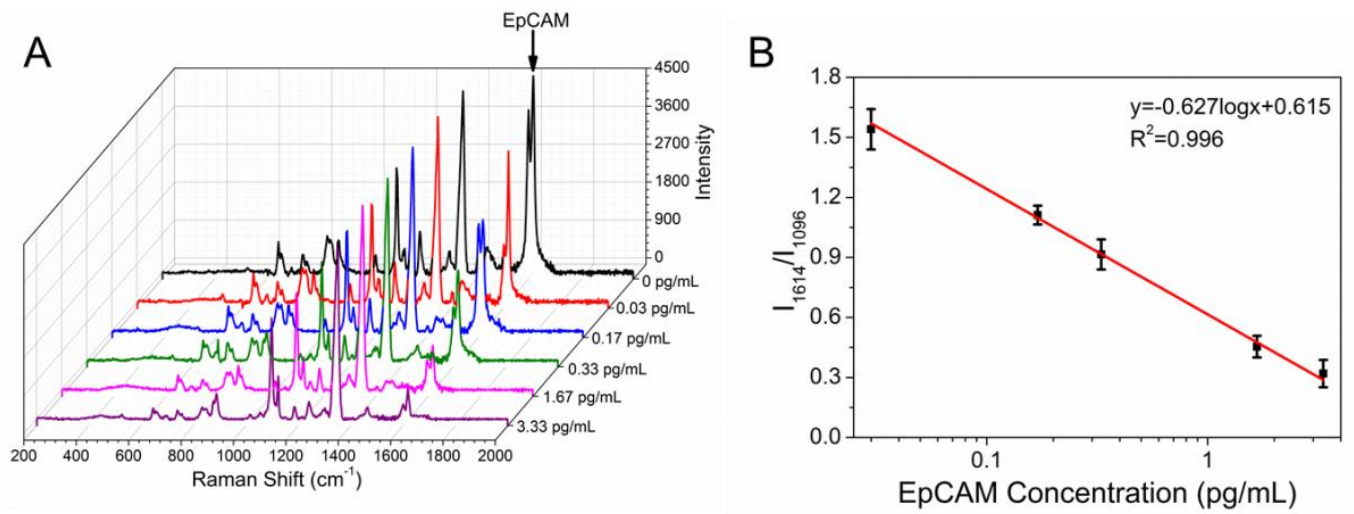

18

Figure S5. Probes for EpCAM in vitro detection. A) SERS spectra of probes responded to different concentrations of $\operatorname{EpCAM}(0,0.03,0.17,0.33,1.67$, and 3.33 $\mathrm{mg} / \mathrm{mL})$ in PBS. B) A plot of Raman intensity ratio $\left(\mathrm{I}_{1614} / \mathrm{I}_{1096}\right)$ as a function with different concentrations EpCAM in PBS. 


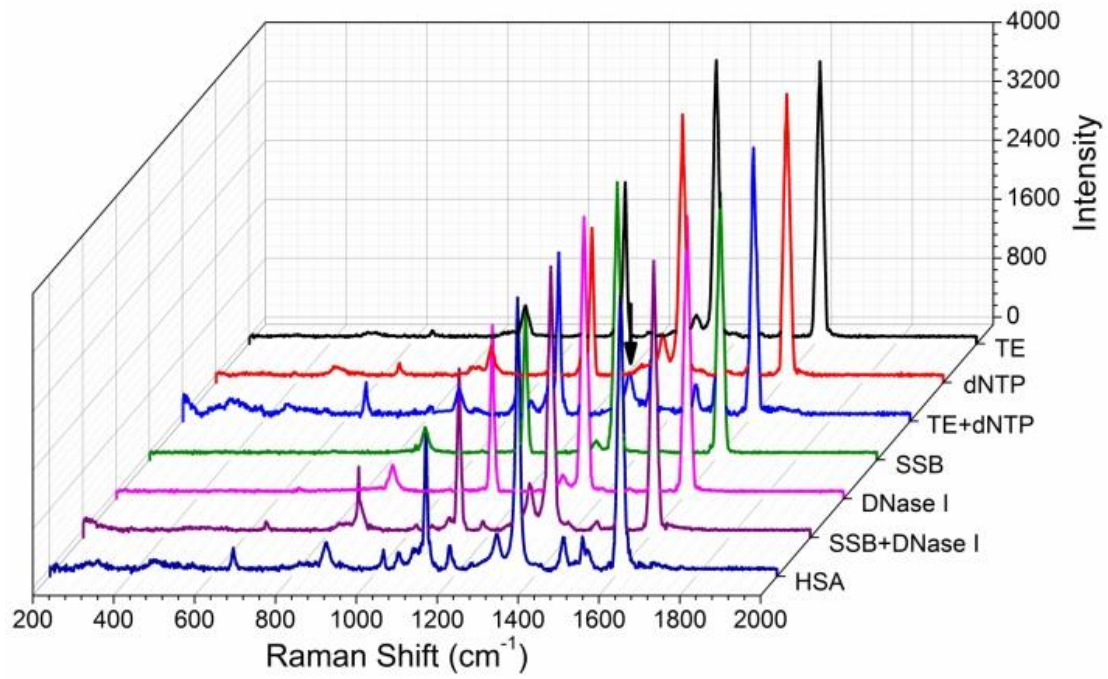

24

25 Figure S6. Raman intensity $\left(1346 \mathrm{~cm}^{-1}\right)$ discrimination of probes to TE only, dNTP 26 only, SSB (1 mM), DNase I (10 IU/L) and HSA (1 mM).

27 


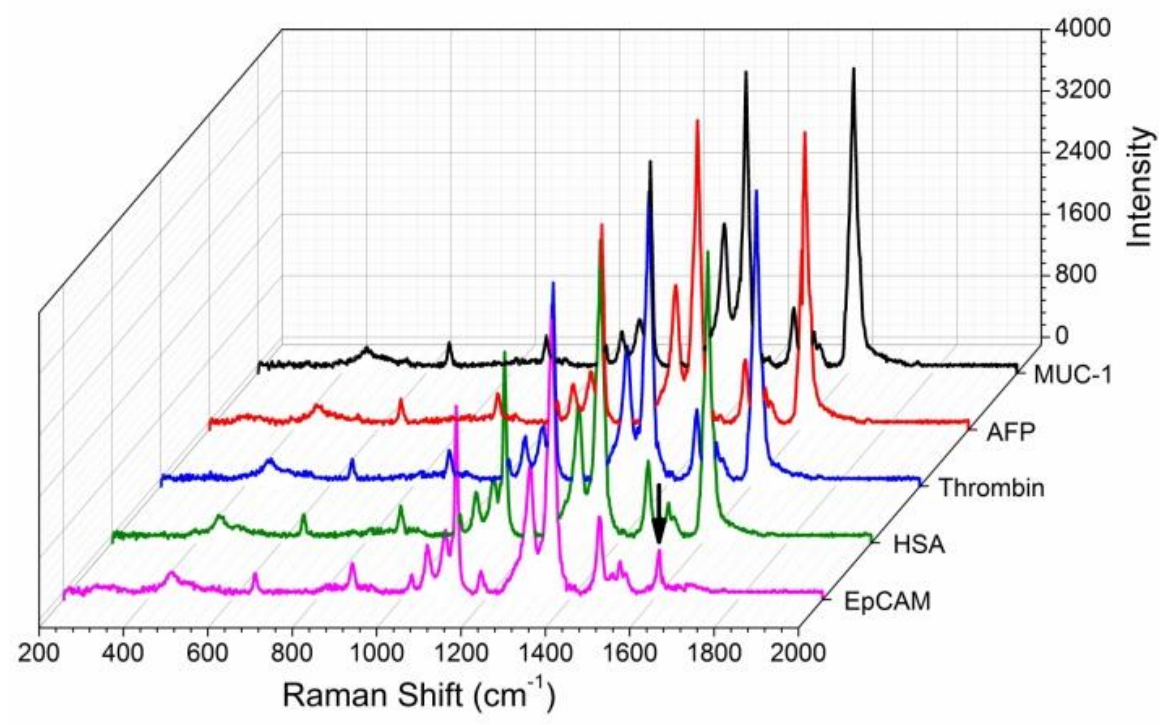

Figure S7. Raman intensity $\left(1614 \mathrm{~cm}^{-1}\right)$ discrimination of probes to MUC-1 $\left(1 \times 10^{-12}\right.$ $\mathrm{M}) \operatorname{AFP}\left(1 \times 10^{-3} \mathrm{M}\right)$, thrombin $\left(1 \times 10^{-12} \mathrm{M}\right)$, and HSA $\left(1 \times 10^{-12} \mathrm{M}\right)$. 


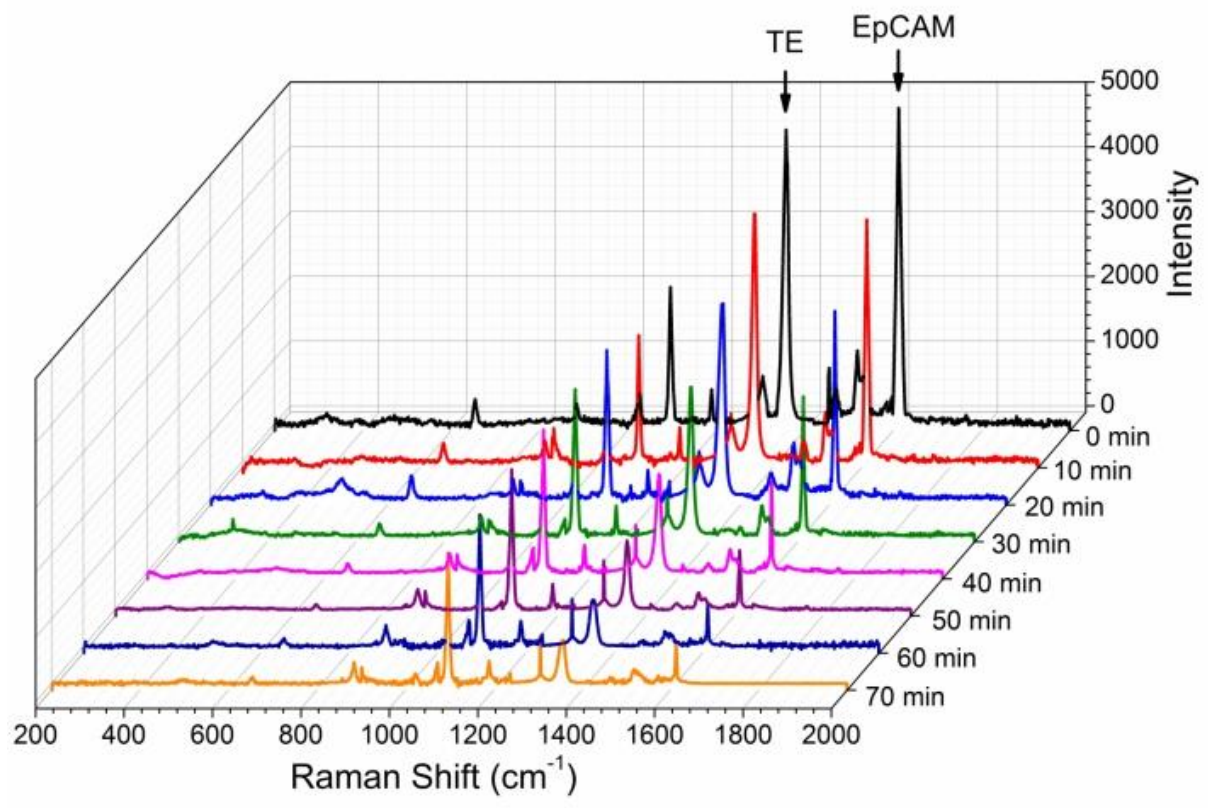

Figure S8. SERS spectra of probes incubated with TE and EpCAM at 0-70 min in 34 PBS. 


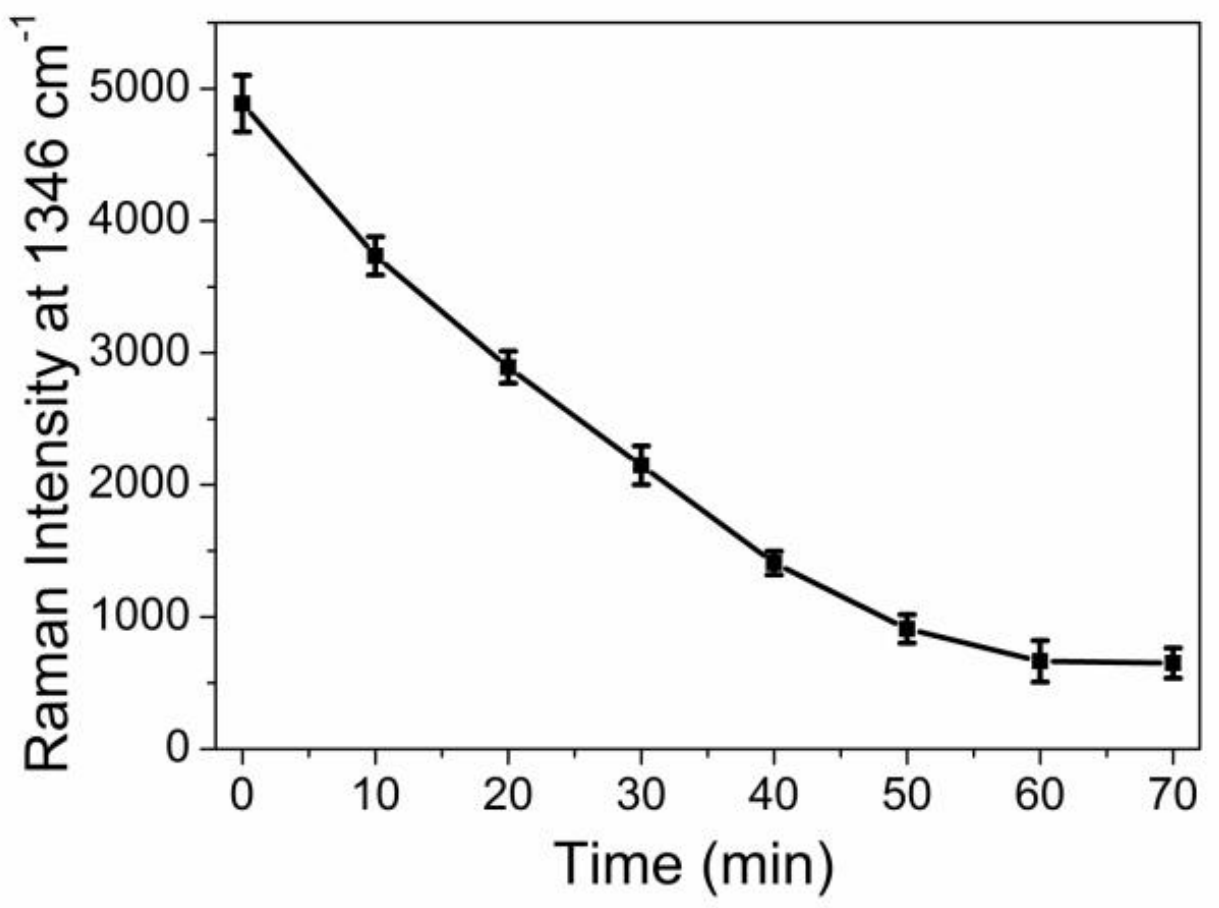

36

37 Figure S9. Plot of SERS intensity at $1346 \mathrm{~cm}^{-1}$ after probes incubating with TE and 38 EpCAM for different time in PBS.

39 


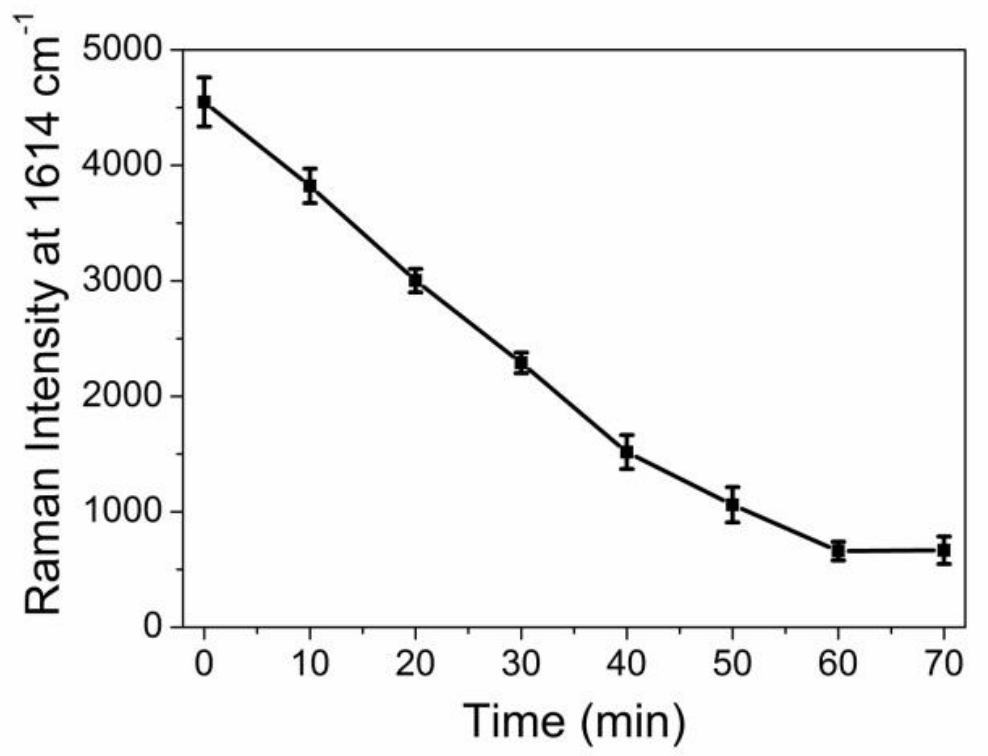

40

41 Figure S10. Plot of SERS intensity at $1614 \mathrm{~cm}^{-1}$ after probes incubating with TE and 42 EpCAM for different time in PBS.

43 


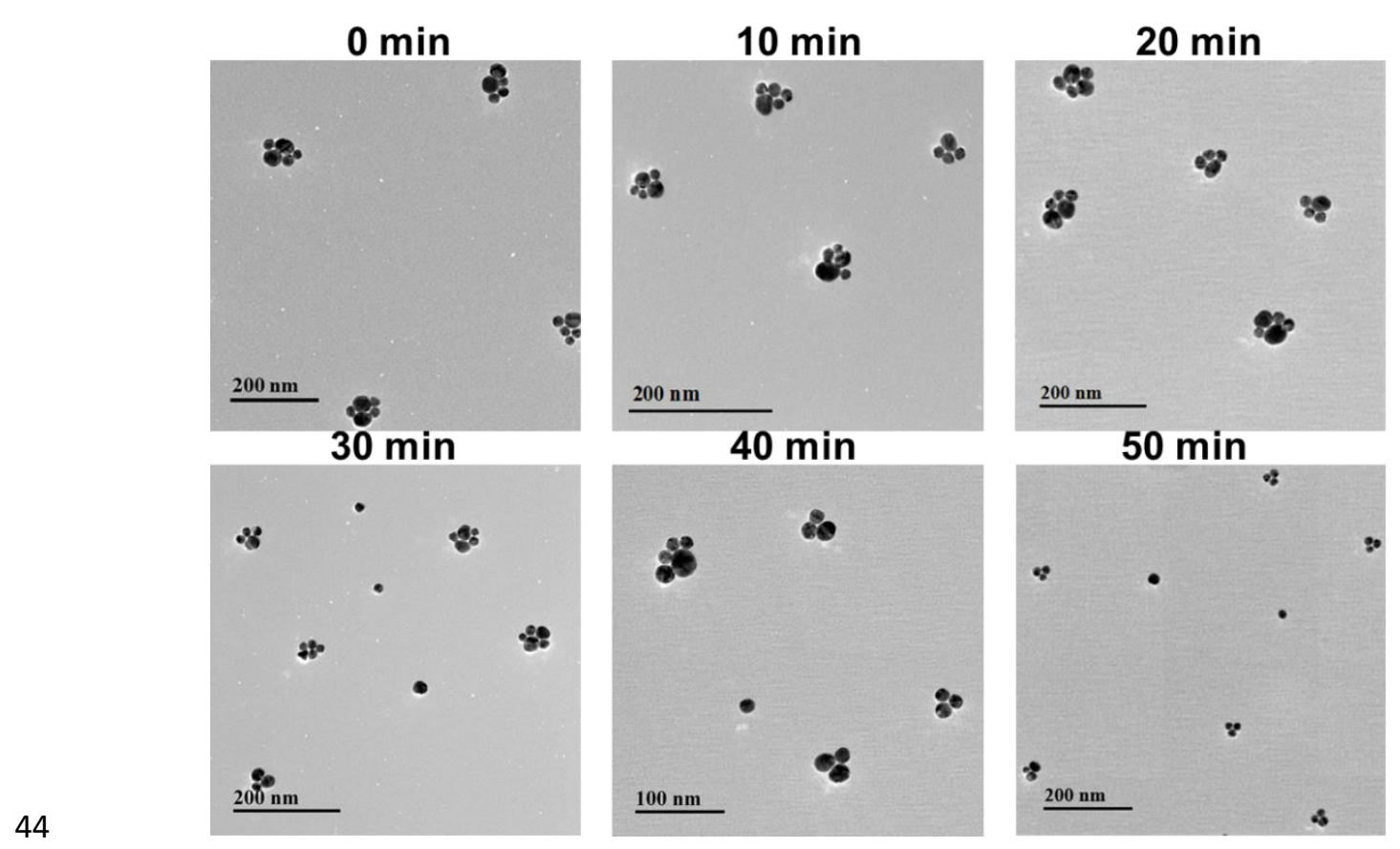

45

Figure S11. Probes incubated with TE and EpCAM at 0-50 min in PBS. 


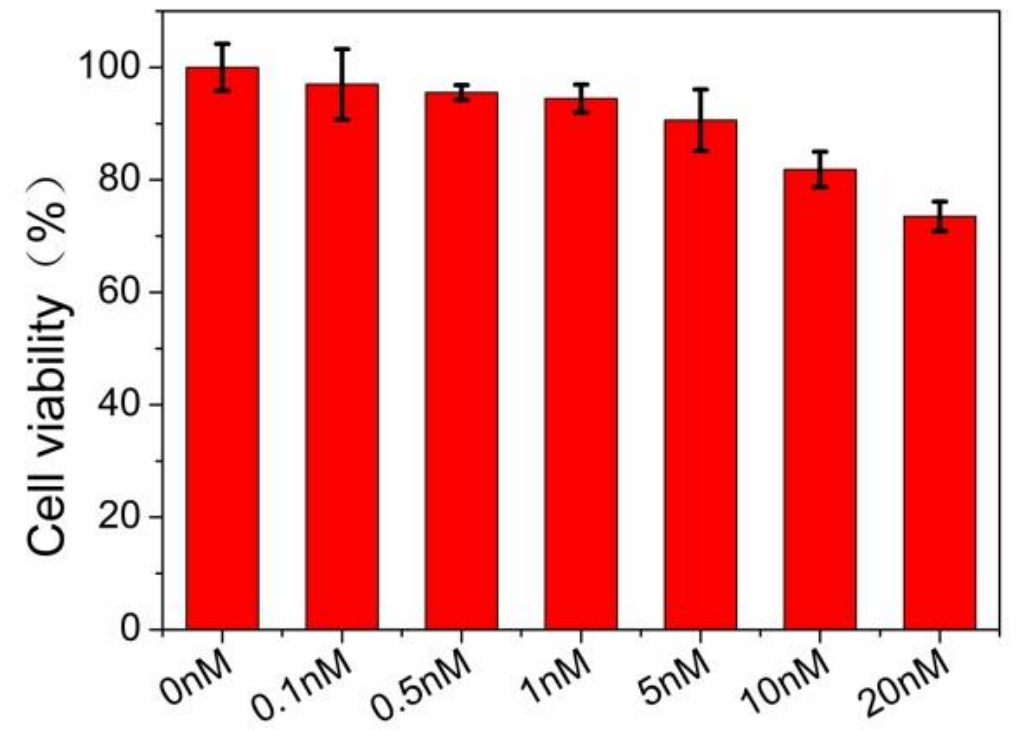

47

Figure S12. Cytotoxicity of HeLa cells with different concentrations probes.

49 


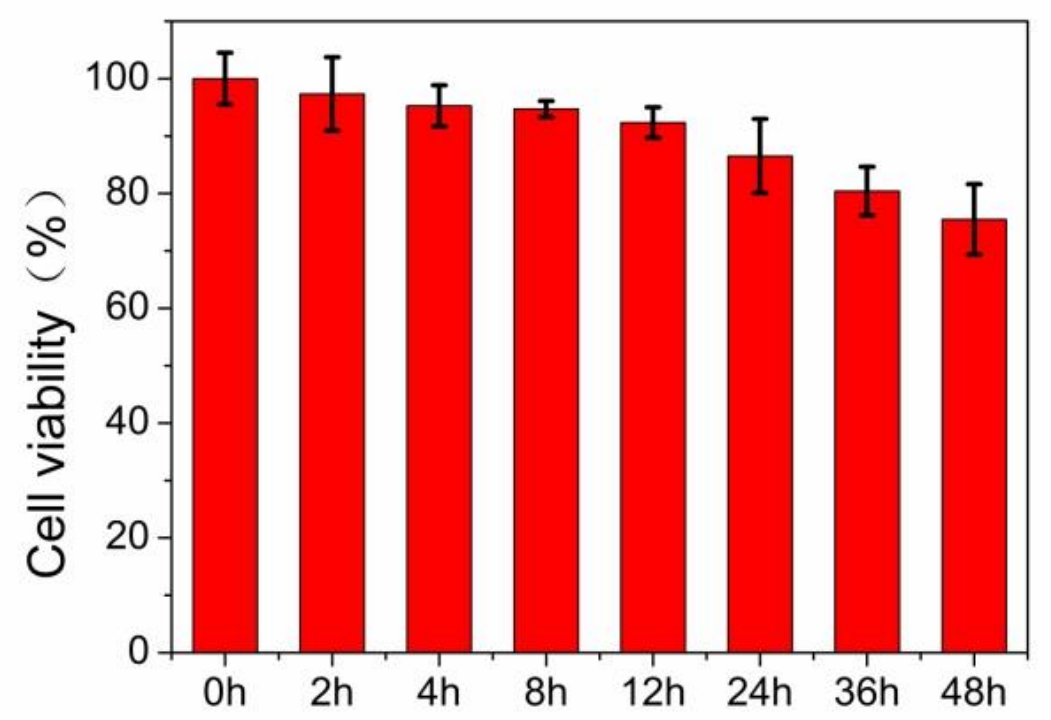

51

52 Figure S13. Viability of HeLa cells $\left(100 \mu \mathrm{L}, 1.0 \times 10^{6} \mathrm{~mL}^{-1}\right)$ after incubation with 5 53 $\mathrm{nM}$ probes for different times.

54 


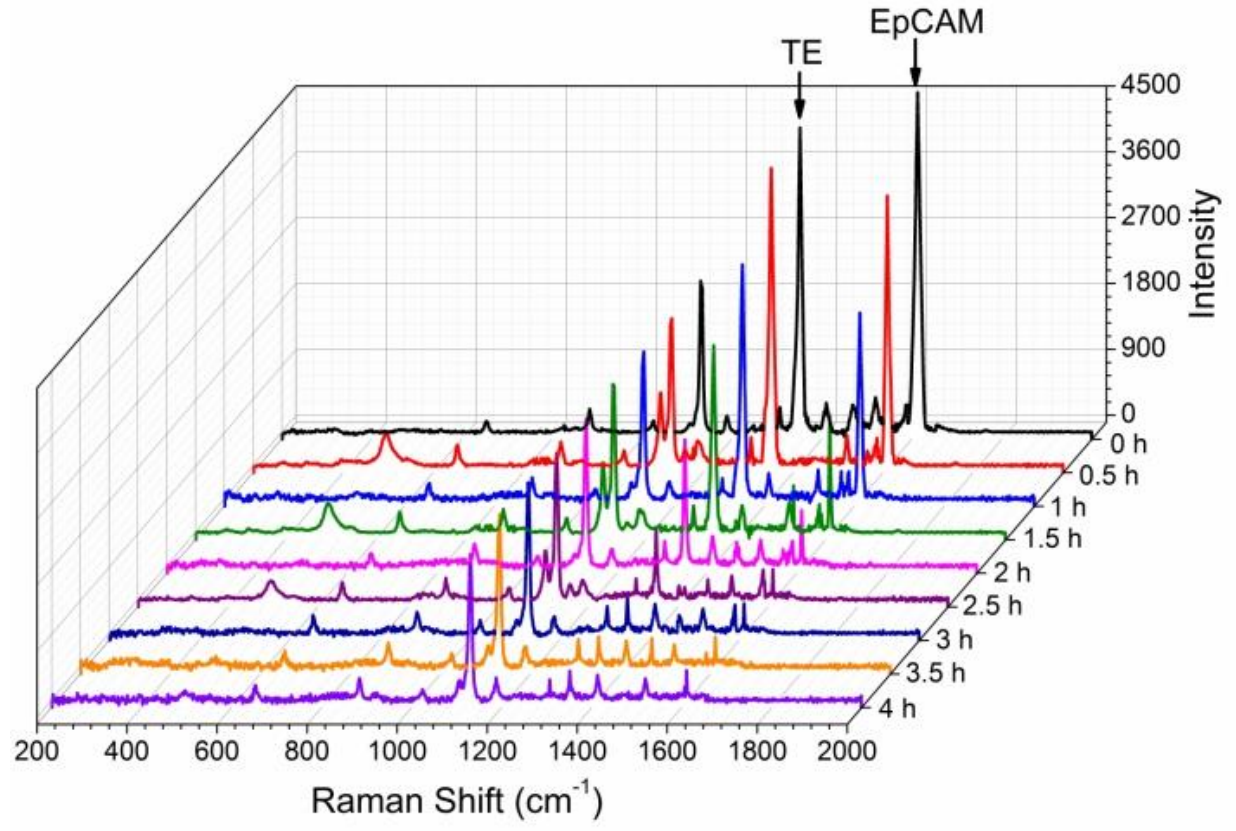

55

Figure S14. Intracellular SERS spectra of probes incubated with HeLa cells at 0-4 h. 


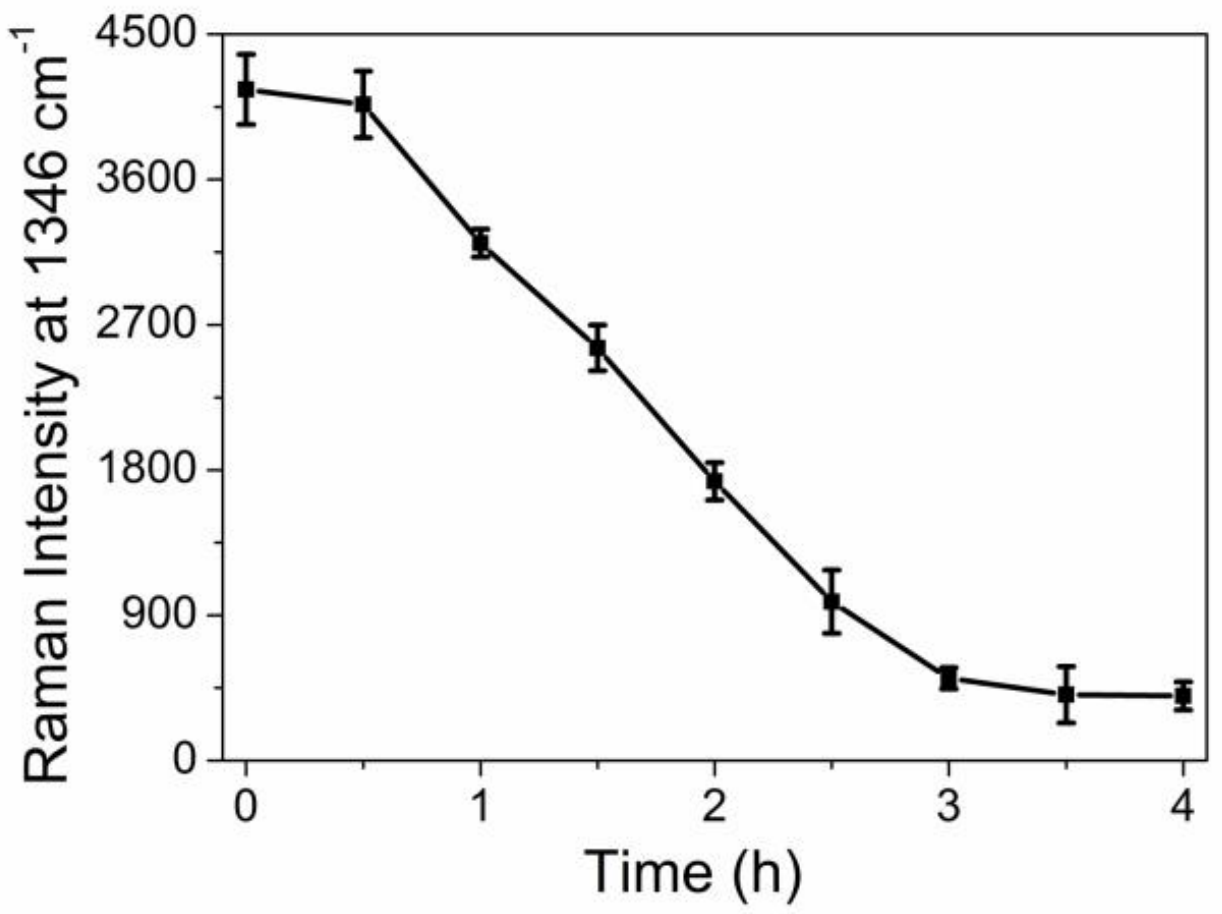

58

59 Figure S15. Plot of SERS intensity at $1346 \mathrm{~cm}^{-1}$ after incubating probes with HeLa 60 cells for different time.

61 


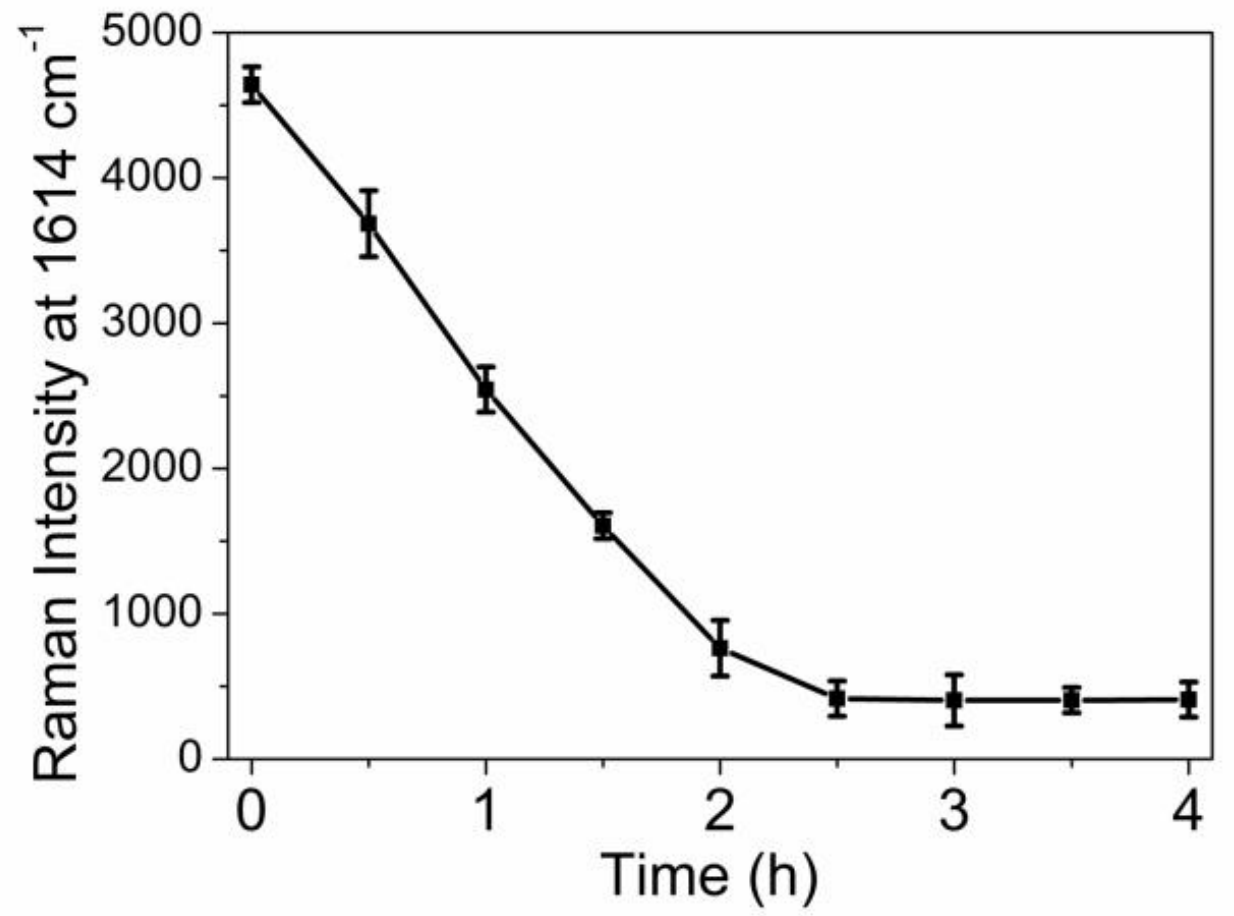

62

63 Figure S16. Plot of SERS intensity at $1614 \mathrm{~cm}^{-1}$ after incubating probe with HeLa 64 cells for different time.

65 
A

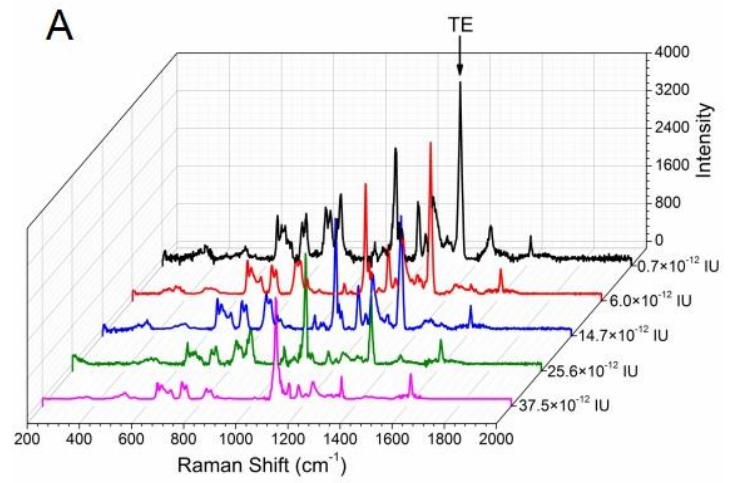

B

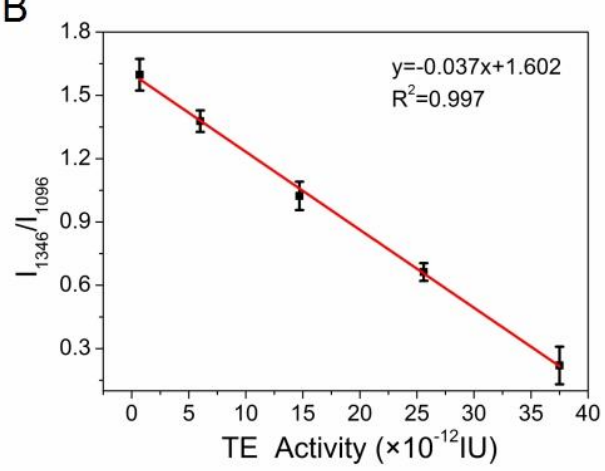

67

68

69

70

71

Figure S17. Probes for TE detection in HeLa cells. A) SERS spectra of probes responded to different activity of TE $\left(0.7,6,14.7,25.6\right.$ and $\left.37.5 \times 10^{-12} \mathrm{IU}\right)$. B) A standard curve of Raman intensity ratio $\left(\mathrm{I}_{1346} / \mathrm{I}_{1096}\right)$ and different avtivity TE in HeLa cells. 

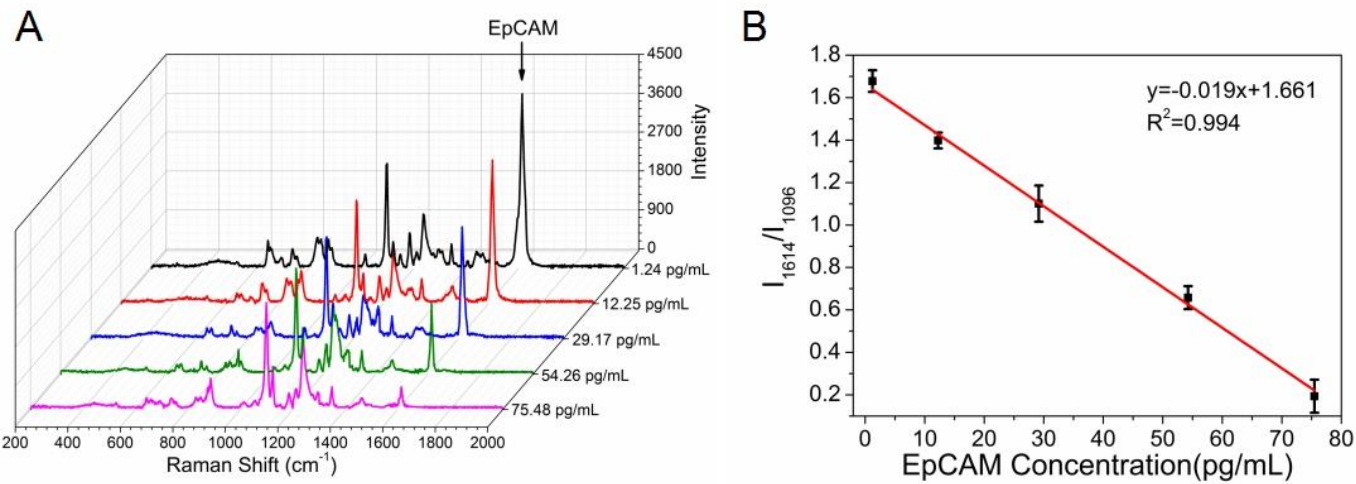

72

Figure S18. Probes for EpCAM detection in HeLa cells. A) SERS spectra of probes responded to different concentration of $\operatorname{EpCAM}(1.24,12.25,29.17,54.26$ and 75.48 $\mathrm{pg} / \mathrm{mL})$. B) A standard curve of Raman intensity ratio $\left(\mathrm{I}_{1614} / \mathrm{I}_{1096}\right)$ and different concentration of EpCAM in HeLa cells. 


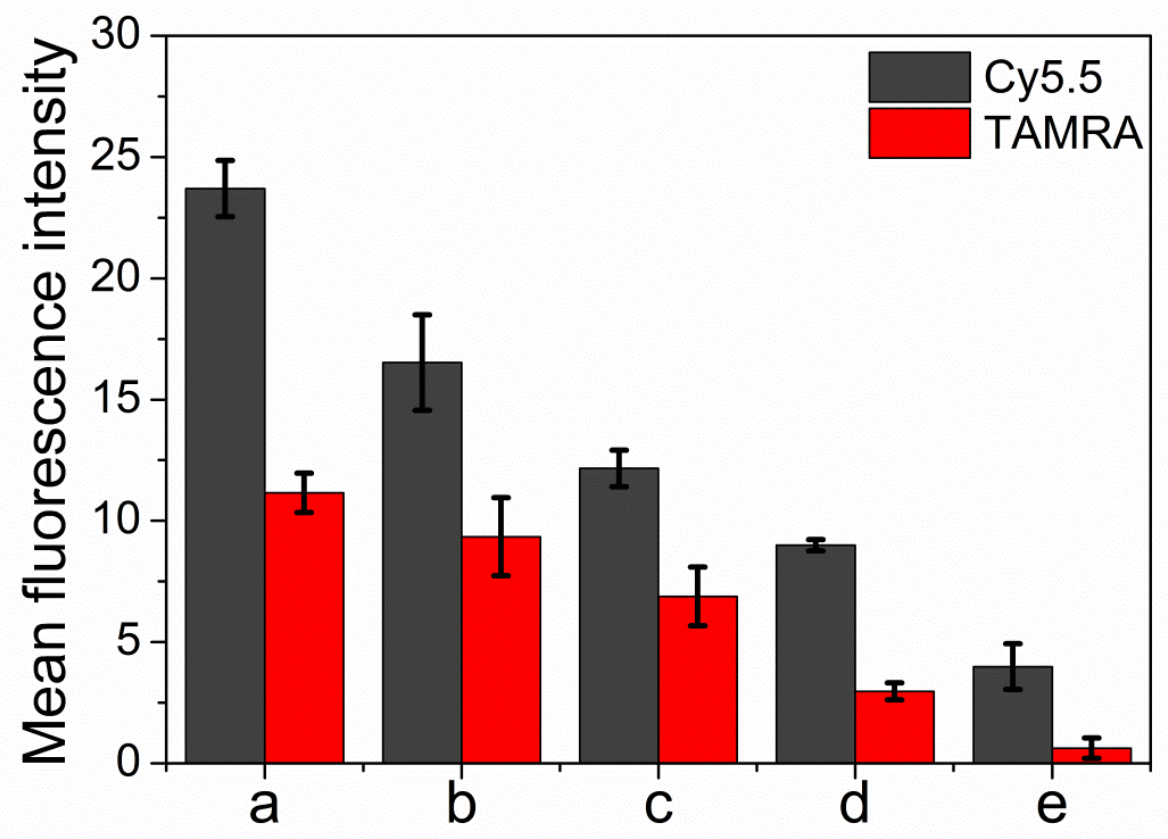

79

80 Figure S19. Fluorescence emission values for HeLa cells with different levels of TE and EpCAM simultaneously (for conditions from a to e, see Figure 3). 


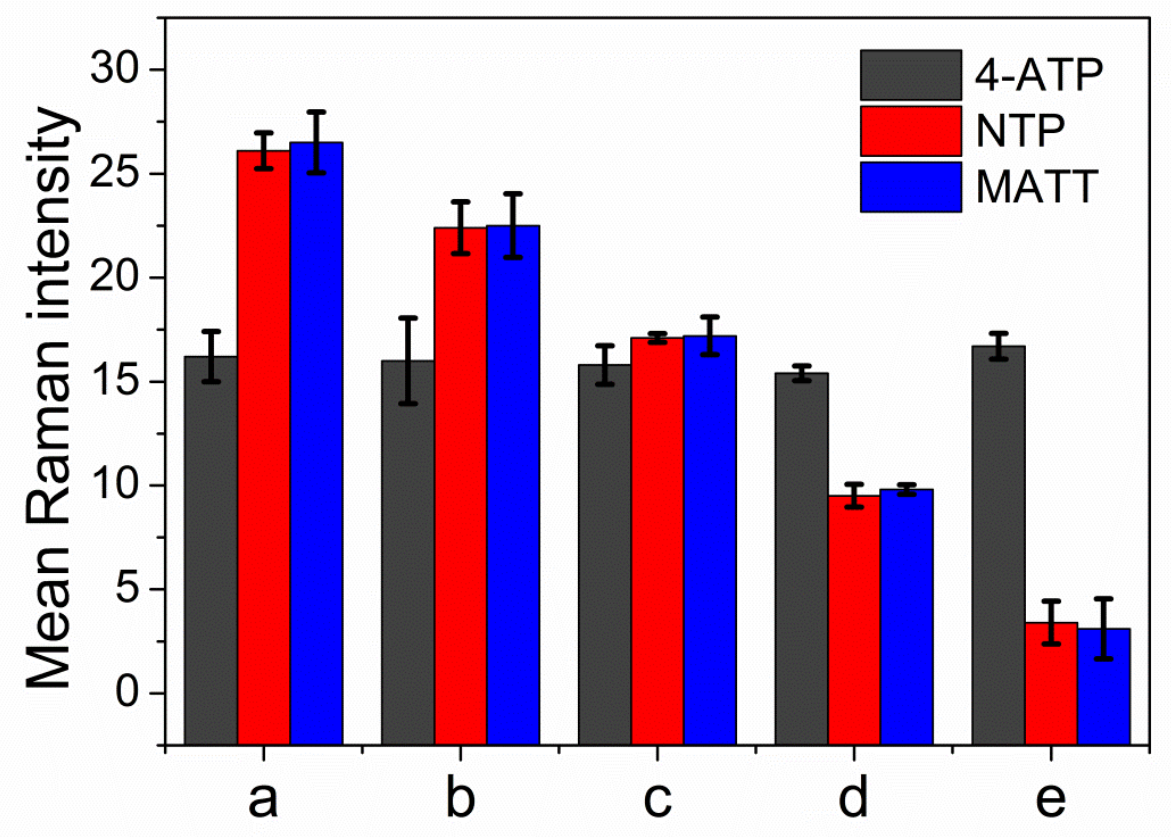

83

84 Figure S20. Mean Raman intensity values for HeLa cells with different levels of TE

85 and EpCAM simultaneously (for conditions from a to e, see Figure 3).

86 


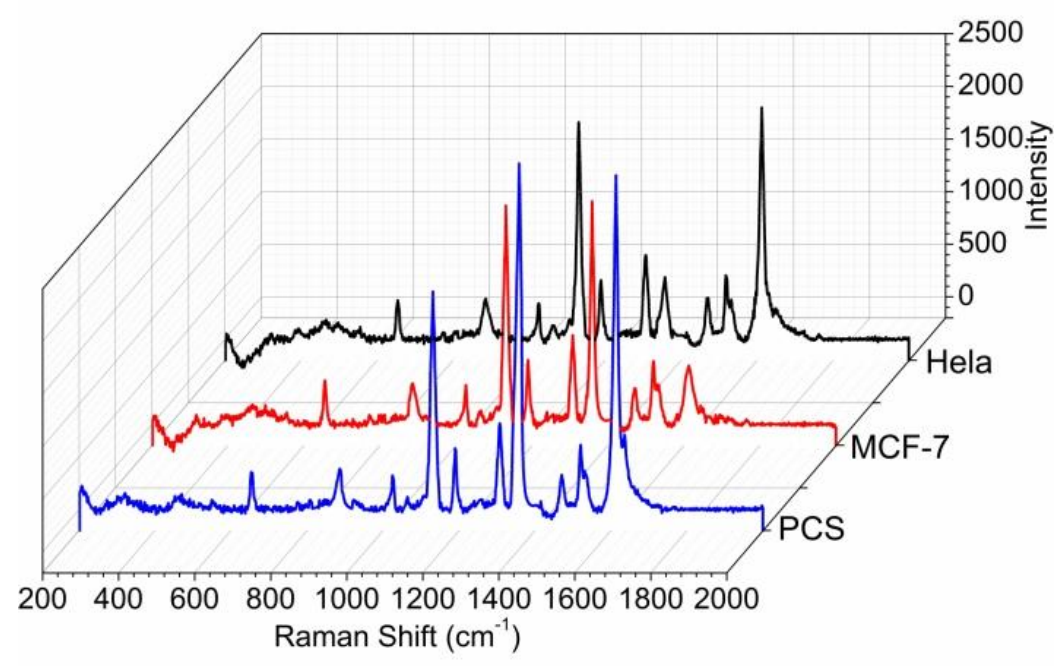

87

88 Figure S21. Intracellular SERS spectra for HeLa, MCF-7, PCS cells incubated with 89 probes.

90 


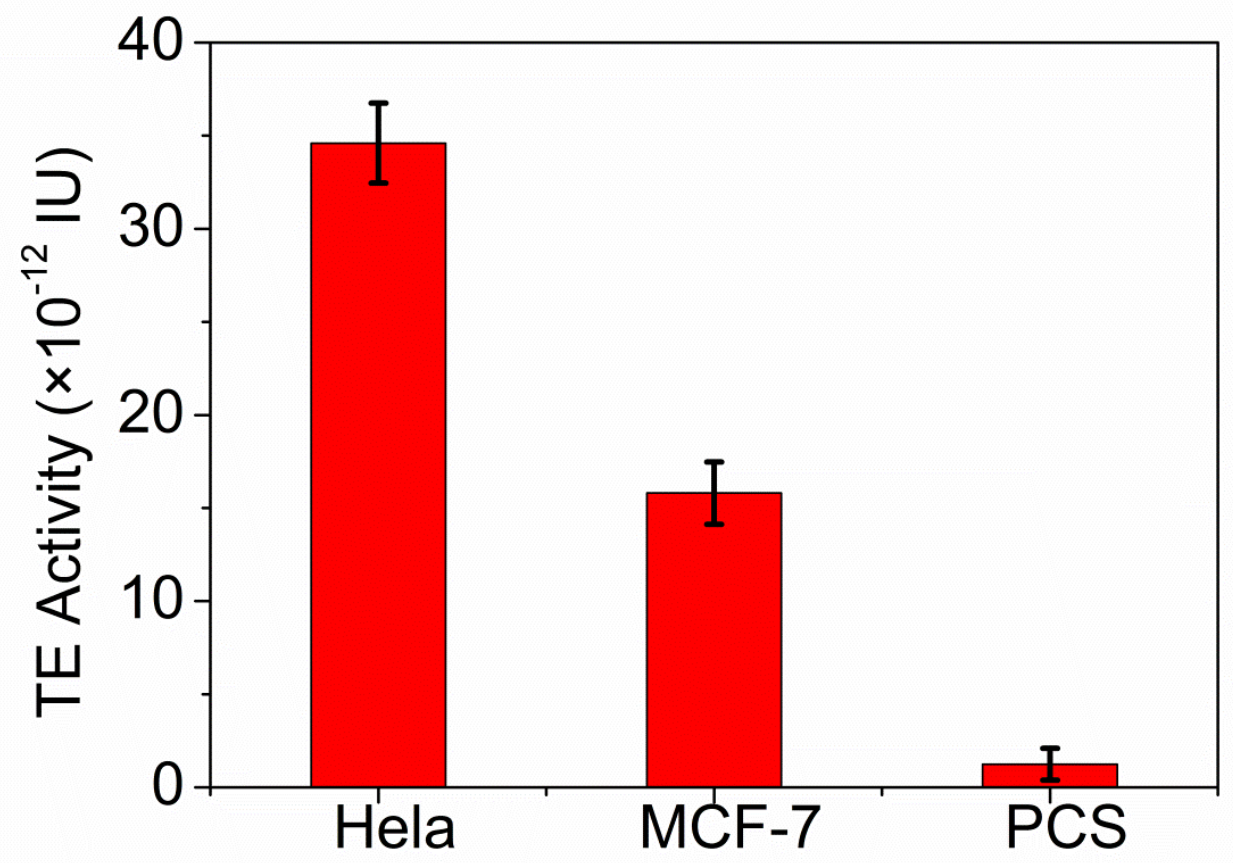

91

92

Figure S22. The obtained TE activity in different cells.

93 


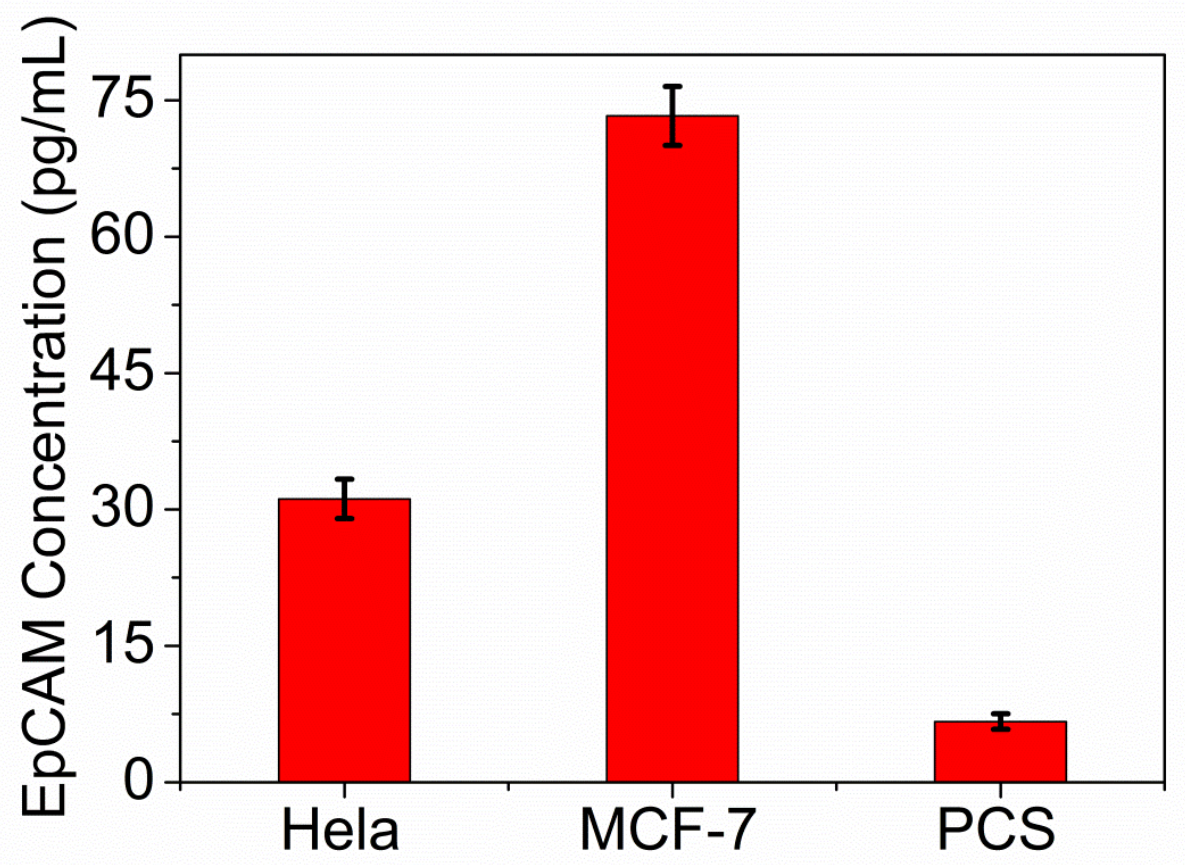

94

Figure S23. The obtained EpCAM concentration in different cells. 


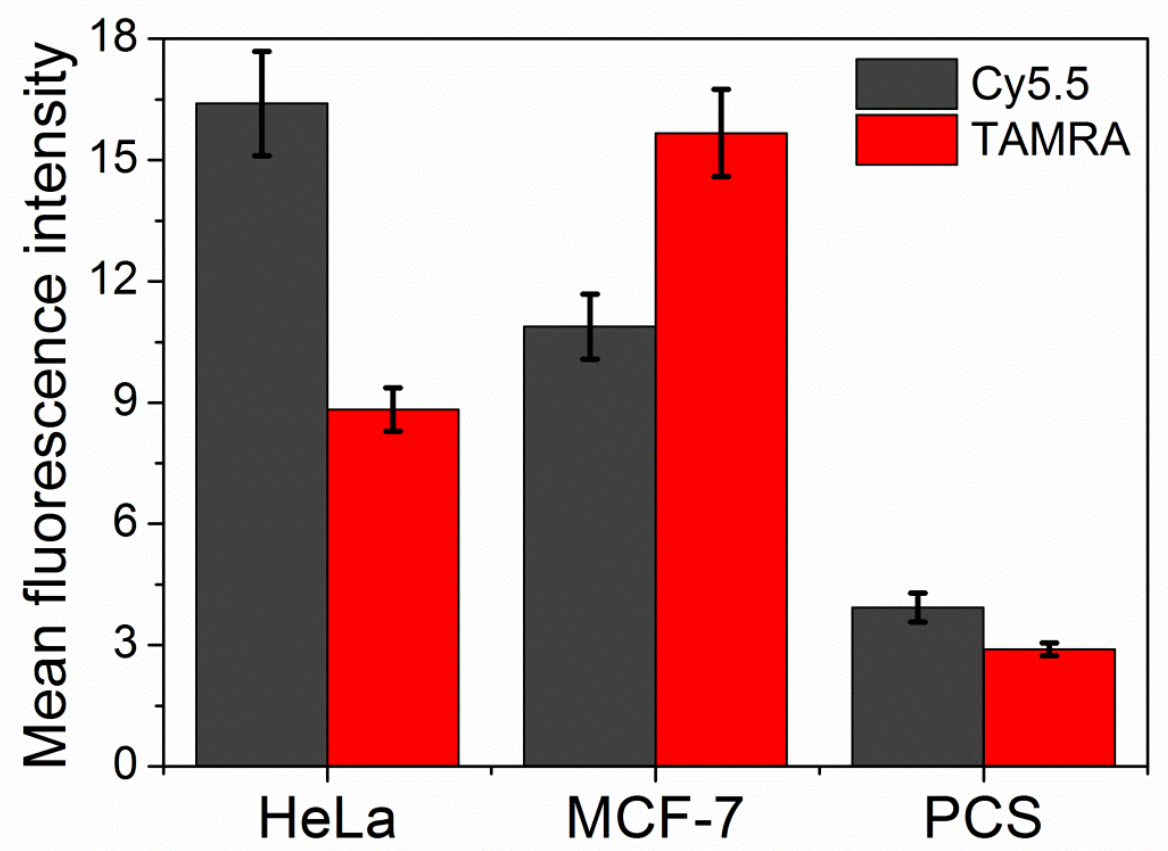

97

Figure S24. Fluorescence emission values for HeLa, MCF-7, PCS cells after incubated with probes. 


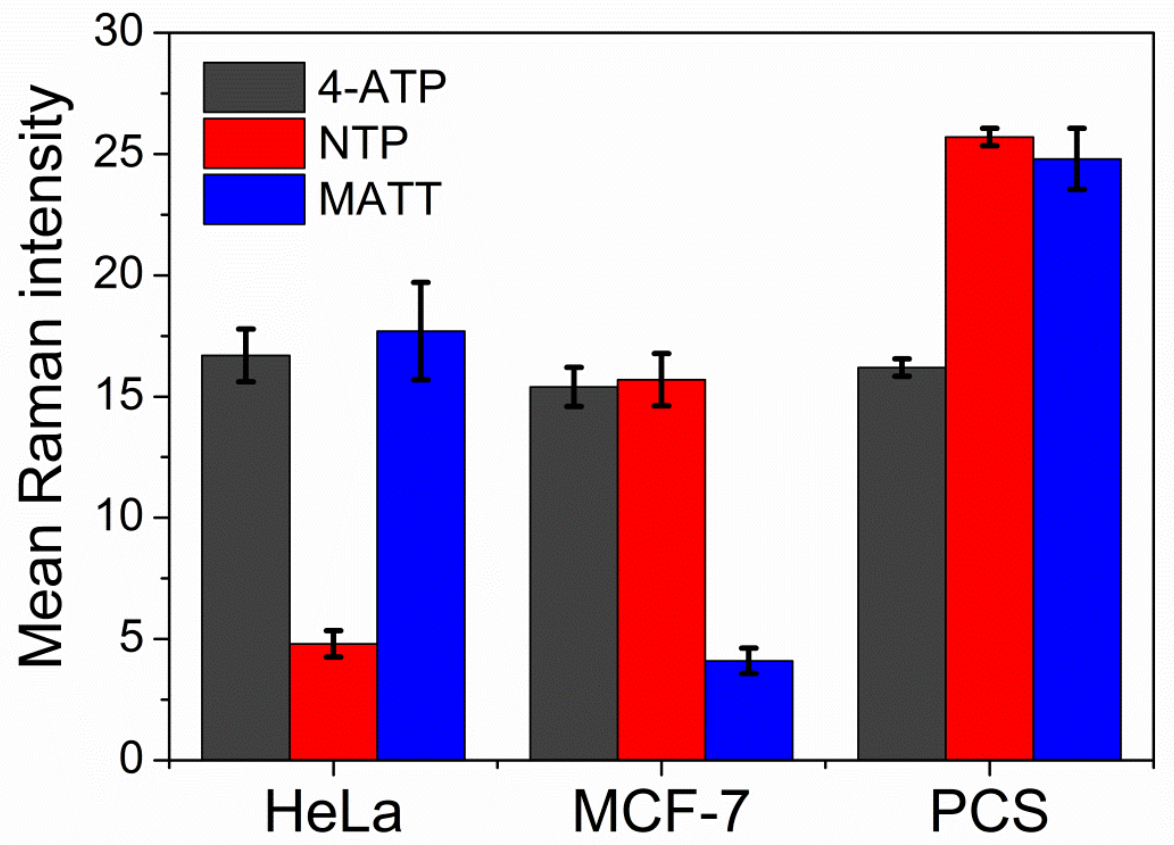

101

Figure S25. Mean Raman intensity values for HeLa, MCF-7, PCS cells after 103 incubated with probes. 